\title{
BIOPOLÍTICA, RACISMO E VIDA NUA: QUANDO O SOL NÃO NASCE PARA TODOS
}

\section{BIOPOLITICS, RACISM AND NAKED LIFE: WHEN THE SUN DOESN'T RISE FOR EVERYONE}

\author{
Maiquel Ângelo Dezordi Wermuth ${ }^{1}$ \\ André Giovane de Castro ${ }^{2}$ \\ "A carne mais barata do mercado é a carne negra \\ Que vai de graça pro presídio \\ E para debaixo do plástico \\ Que vai de graça pro subemprego \\ E pros hospitais psiquiátricos"
} (Seu Jorge, Marcelo Yuca e Wilson Capellette)

\section{RESUMO}

O artigo aborda o tema da biopolítica e do racismo de Estado em face da população negra no Brasil. A problemática envolve a forma pela qual o racismo, como instrumento de justificação da morte direta ou indireta em uma sociedade marcada pela biopolítica, afeta os negros na Contemporaneidade em relação à persecução penal e à violência. A hipótese originária deste trabalho acadêmico evidencia a utilização do racismo como indispensável à eliminação, via morte e segregação, dos negros considerados como raça impura, ruim, perigosa e desnecessária para os fins da sociedade e do Estado. A investigação científica, à luz do método fenomenológico-hermenêutico, da abordagem qualitativa, da técnica exploratória e dos procedimentos bibliográfico e documental, objetiva estudar criticamente a formação e a vinculação da biopolítica com o racismo, o modo de realização do racismo frente aos negros, principalmente no Brasil, e a situação da população negra sob a perspectiva da biopolítica. A pesquisa, por fim, concebe a existência dos negros atrelada à condição de homo sacer, retratada

\footnotetext{
${ }^{1}$ Doutor e mestre em Direito pela Universidade do Vale do Rio dos Sinos (UNISINOS). Especialista em Direito Penal e Direito Processual Penal e bacharel em Direito pela Universidade Regional do Noroeste do Estado do Rio Grande do Sul (UNIJUÍ). Coordenador e Professor do Programa de Pós-Graduação Stricto Sensu em Direito Mestrado e Doutorado em Direitos Humanos - da UNIJUÍ. Professor dos Cursos de Graduação em Direito da UNIJUÍ e da UNISINOS. Coordenador da Rede de Pesquisa Direitos Humanos e Políticas Públicas. Líder do Grupo de Pesquisa: Biopolítica e Direitos Humanos (CNPq). Pesquisador Gaúcho (FAPERGS). Universidade Regional do Noroeste do Estado do Rio Grande do Sul - UNIJUÍ, Rio Grande do Sul; Universidade do Vale do Rio dos Sinos, UNIJUÍ, Rio Grande do Sul. - Brasil. ORCID: http://orcid.org/0000-0002-7365-5601 Lattes: http://lattes.cnpq.br/0354947255136468 E-mail: madwermuth@gmail.com

${ }^{2}$ Doutorando e mestre em Direito pelo Programa de Pós-Graduação Stricto Sensu em Direito - Mestrado e Doutorado em Direitos Humanos - da Universidade Regional do Noroeste do Estado do Rio Grande do Sul (UNIJUÍ). Bacharel em Direito pela UNIJUÍ. Bolsista da Coordenação de Aperfeiçoamento de Pessoal de Nível Superior (CAPES). Integrante do Grupo de Pesquisa: Biopolítica e Direitos Humanos (CNPq). Universidade Regional do Noroeste do Estado do Rio Grande do Sul - UNIJUÍ, Rio Grande do Sul. - Brasil. ORCID: http://orcid.org/0000-0002-8970-5685 Lattes: http://lattes.cnpq.br/6492360525985954 E-mail:
} andre_castro500@hotmail.com 
pela vida nua, desprovida de direitos humanos e eliminável do tecido político-social, no disseminado estado de exceção em vastos campos contemporâneos.

Palavras-chave: Biopolítica; Homo sacer; Negros; Racismo de Estado; Vida nua.

\begin{abstract}
The article addresses the issue of biopolitics and State racism in the face of the black population in Brazil. The issue involves the way in which racism, as an instrument of justification for direct or indirect death in a society marked by biopolitics, affects blacks in Contemporary times in relation to criminal persecution and violence. The original hypothesis of this academic work highlights the use of racism as indispensable to the elimination, through of death and segregation, of blacks considered as an impure, bad, dangerous and unnecessary race for the purposes of society and the State. The scientific investigation, in the light of the phenomenological-hermeneutic method, the qualitative approach, the exploratory technique and the bibliographical and documentary procedures, aims to critically study the formation and the linkage of biopolitics with racism, the way racism is carried out in relation to blacks, especially in Brazil, and the situation of the black population from the perspective of biopolitics. Finally, the research conceives the existence of blacks linked to the condition of homo sacer, portrayed by the naked life, deprived of human rights and eliminable from the political-social structure, in the widespread state of exception in vast contemporary fields.
\end{abstract}

Keywords: Biopolitics; Homo sacer; Blacks; State racism; Naked life.

\title{
1 CONSIDERAÇÕES INICIAIS
}

A configuração e a realização do poder do Estado sofreram significativas alterações a partir do século XVII. O filósofo Michel Foucault, ao debruçar-se sobre a estruturação dos mecanismos de manifestação de comando, encontrou no florescer da Modernidade a ascensão de técnicas de disciplinamento e controle que são complementares e superpostas, quais sejam: a anátomo-política do corpo humano e a biopolítica da população.

A anátomo-política tem como cerne a individualização dos corpos, ao passo que a biopolítica - o marco basilar deste estudo - se alicerça em regulações globais dos seres humanos. O fim do século XVIII e o início do século XIX elevaram a vida à condição de objeto e instrumento da política, com o que a administração estatal se firmou em controlar taxas de natalidade, mortalidade, patologias, engenharias urbanas, etc.

A biopolítica, no seio do tecido político-social atual, tem na vida a sua manifestação. No entanto, a melhoria das condições de vida, vez ou outra, demanda a eliminação de certas populações em benefício de outras. Para validar a morte, direta ou indireta, de alguns em prol 
de outros, surgiu aquilo que a filosofia foucaultiana conceitua como racismo de Estado e que constitui a seletividade das raças que merecem, ou não, viver.

A discussão acerca do racismo é, a partir disso, tomada como necessária à luz do processo penal, da execução criminal e da violência a que são submetidos os negros, especialmente no Brasil. A análise da cor da pele como elemento influenciador de uma sociedade biopolítica pode ser desenvolvida com base na filosofia de Giorgio Agamben e suas teorias em torno da figura do homo sacer, da vida nua, do estado de exceção e do campo.

Assim, a presente pesquisa, consubstanciada, sobretudo, nas teses foucaultianas e agambenianas, tem como norte o seguinte problema: em que medida o racismo de Estado, como instrumento de justificação da morte direta ou indireta em uma sociedade biopolítica, afeta a população negra na Contemporaneidade em relação ao processo penal, à execução criminal e à violência, com ênfase no cenário brasileiro?

O estudo emerge da hipótese, com efeito, da existência de uma governamentalidade, baseada na biopolítica e, logo, no poder de selecionar, em terras brasileiras. Por meio dela, a utilização do racismo é vislumbrada como inevitável à eliminação, mediante a morte ou a exclusão no âmbito do encarceramento, da população negra, haja vista sê-la concebida como raça impura, ruim, perigosa e desnecessária para os fins da sociedade e do Estado.

O trabalho tem, na mesma ordem das suas seções, os seguintes objetivos: a) analisar a assunção e a vinculação da biopolítica com o racismo de Estado; b) desvelar a realização do racismo frente à população negra, especialmente no Brasil, a partir do livro $O$ sol é para todos, de Harper Lee, e informes estatísticos sobre encarceramento e violência; e c) refletir a situação dos negros à luz das categorias de homo sacer, vida nua, estado de exceção e campo.

A adoção do método fenomenológico-hermenêutico, com base nas lições teóricas de Martin Heidegger (1998) e Hans-Georg Gadamer (1999), mostra-se oportuna em virtude de autorizar o alcance dos intentos deste trabalho acadêmico. Não se busca tão só descrever a realidade. A ambição central é desvelar as nuanças envolventes do cenário, essencialmente no Brasil, no tocante à situação de violência institucional e social em face dos negros.

O referido método constitui-se como condição de possibilidade para o desabrochar dos meandros do poder, no bojo do qual os sujeitos-pesquisadores sentem os seus efeitos, e para a observância da cientificidade. A subjetividade entra em simbiose com a objetividade. Com alicerce na historicidade e na tradição, à luz das teorias filosóficas heideggeriana (1998) e gadameriana (1999), este método viabiliza o desvelamento das coisas em si mesmas. 
A fenomenologia, definida como estudo do fenômeno, vincula-se com a hermenêutica, definida como instrumento de vislumbre do assunto. Assim, o sobredito método oportuniza, a teor de Ernildo Stein (2001, p. 169), o acesso "ao fenômeno no sentido fenomenológico", de modo a descortinar o que "primeiramente e o mais das vezes não se dá como manifesto". Essa é, aliás, a missão dos sujeitos-pesquisadores.

A investigação científica adota, portanto, o método fenomenológico-hermenêutico, a abordagem qualitativa, a técnica exploratória e os procedimentos bibliográfico e documental, com subsídio em materiais disponíveis em formatos impresso e digital. A fundamentação teórica, selecionada mediante leitura e fichamento, é acrescida de literatura ficcional, como acima indicado, e de informes estatísticos sobre o encarceramento e a criminalidade no País.

\section{BIOPOLÍTICA E RACISMO: ENTRE A VIDA E A MORTE}

A vivência dos seres humanos encontra-se extensivamente regulada e controlada pelo Estado. A instituição estatal, notadamente a partir da Modernidade, desempenha funções sobre a singularidade e a coletividade dos cidadãos. O indivíduo, na sua condição de corpo ou espécie, alcança o status de objeto e de instrumento do poder constituído e desenvolvido com base na noção de contrato social.

A rotina de constante insegurança e medo no âmbito do Estado de natureza, no qual, segundo Thomas Hobbes (2017), todos os seres humanos mantinham-se em permanente luta pela sobrevivência, provocou a edificação do Estado. Tal ente, ao surgir como meio de garantir a harmonia e a paz ao tecido societal, recebeu o poder de administrar a vida em sociedade e eliminar o clima de contínua guerra entre os pares.

A submissão do indivíduo ao controle e ao domínio de um poder, que não somente o seu, decorre da precariedade da fruição dos direitos no seio do Estado de natureza. Embora existam direitos naturais, os seus detentores mantêm-se sob a contínua ameaça de violação. Nesse sentido, na lição de John Locke (2014, p. 76), a submissão, resultante da abdicação das liberdades, viabiliza "segurança, conforto e paz".

O poder outorgado à instituição estatal está atrelado, conforme Jean-Jacques Rousseau (2015), à entrega de parcela das liberdades individuais para a formação do soberano. O pacto social, assim, realizado consensualmente, restringiu a absoluta liberdade exercida no Estado de natureza, mas, ao mesmo tempo, ensejou a igualdade formal dos homens e das mulheres, além de incumbir o Estado civil de proteger, substancialmente, a vida dos seres humanos. 
A atuação do ente estatal, com efeito, vincula-se com os almejos fundantes desta nova ordem social. A partir dessa perspectiva, Michel Foucault (1999) condiciona ao Estado, com ênfase ao século XVII em diante, a criação de dois mecanismos de poder centrados no corpo e na vida emergentes com base em uma ideia de docilidade, utilidade e controle dos cidadãos: a anátomo-política e a biopolítica.

Para a vertente foucaultiana (1999), a anátomo-política e a biopolítica, concebidas como dois meios de exercício do poder, surgiram em momentos históricos distintos, haja vista representarem interesses diferentes e se realizarem mediante objetos diversos, sem, contudo, serem antagônicas ${ }^{3}$. Nesse sentido, Foucault (1999, p. 131, grifos do autor) contextualiza a assunção e a exteriorização dos referidos mecanismos da seguinte forma:

[...] Um dos pólos, o primeiro a ser formado, ao que parece, centrou-se no corpo como máquina: no seu adestramento, na ampliação de suas aptidões, na extorsão de suas forças, no crescimento paralelo de sua utilidade e docilidade, na sua integração em sistemas de controle eficazes e econômicos - tudo isso assegurado por procedimentos de poder que caracterizam as disciplinas: anátomo-política do corpo humano. O segundo, que se formou um pouco mais tarde, por volta da metade do século XVIII, centrou-se no corpo-espécie, no corpo transpassado pela mecânica do ser vivo e como suporte dos processos biológicos: a proliferação, os nascimentos e a mortalidade, o nível de saúde, a duração da vida, a longevidade, com todas as condições que podem fazê-los variar; tais processos são assumidos mediante toda uma série de intervenções e contrôles regulares: uma bio-política da população.

O poder focou, inicialmente, no corpo do indivíduo, isto é, na sua singularidade, com o desígnio de desenvolvê-lo e fortalecê-lo em favor dos interesses da sociedade e do soberano. As técnicas disciplinares, características da anátomo-política, de acordo com Foucault (2013), já existiam, por exemplo, em conventos, exércitos e oficinas, mas inovaram ao trazer uma arte do corpo capaz de promover docilidade e utilidade através da constituição de uma mecânica do poder ${ }^{4}$.

\footnotetext{
${ }^{3}$ Sobre o tema, João Paulo Ayub (2015, p. 57) assevera que, na obra foucaultiana, "a separação dos diagramas da anátomo-política e da biopolítica não é radical e muito menos procede a uma substituição histórica precisa; dependendo do dispositivo de saber-poder em questão, pode ocorrer mesmo uma fusão entre esses regimes de poder." No mesmo sentido é a leitura de Edgardo Castro (2011). Nos escritos foucaultianos (2012, p. 151-152), a sobredita perspectiva aparece evidenciada quando o autor assevera que "as disciplinas do corpo e as regulações da população constituem os dois polos em torno dos quais se desenvolveu a organização do poder sobre a vida". Esses polos não são antitéticos, mas se encontram "interligados por todo um feixe intermediário de relações".

${ }^{4}$ O filósofo Michel Foucault (2013) analisa o Panóptico, desenvolvido por Jeremy Bentham em 1785. O modelo panóptico, representado por uma edificação com uma torre central rodeada de celas, corresponde às técnicas disciplinares do Estado, por meio do qual os internos tornam-se obedientes em virtude da sensação de constante vigilância promovida pela abstração do poder presente na torre, mesmo se o vigia, que não pode ser visto, não se encontrar no local.
} 
No transcurso do fim do século XVIII e do início do século XIX, o poder atentou para um novo modo de exteriorização. Ao passo que as disciplinas consistem no adestramento dos corpos por meio da separação, da análise, da diferença, o novo método, consoante a teoria foucaultiana (1999), tem como supedâneo a atenção a elementos como, exemplificativamente, a natalidade, mortalidade, produção e patologia em nível populacional: uma política sobre o homem-espécie.

A população torna-se, com efeito, o objeto e o instrumento do poder. A biopolítica significa, na visão de Foucault (2005), a estatização do biológico em escala coletiva e a assunção da vida como problema político a exigir, diversamente da individualidade própria da anátomo-política, a regulação e o controle populacional através de mecanismos globais de cuidado sobre a vida.

Nesse sentido, considerando a formação da anátomo-política, no século XVII, e da biopolítica, no século XVIII, a estrutura do poder ganha novas configurações. Segundo João Paulo Ayub (2015), a complementação do poder regulador atinente a processos globais ao poder disciplinar sobre o indivíduo forma um conjunto de saberes demográficos, estatísticos, sociológicos e de gestão pública.

As disciplinas e as regulações não são antitéticas, visto terem a condição de atuar em simultaneidade. Além disso, ambas representam uma transformação radical da antiga forma de exercício do poder soberano de matar para a elevação da vida biológica como fator de atenção e cuidado. Para a filosofia foucaultiana (1999), isso significa a alternância de um poder de fazer morrer e deixar viver para um poder de fazer viver e deixar morrer.

A biopolítica, na leitura de Roberto Esposito (2010, p. 60-61), encontra-se no extremo oposto de uma visão puramente negativa do poder soberano, uma vez que, enquanto este "se exercia em termos de subtração, de tributação - dos bens, dos serviços, do sangue - dos próprios súbditos", aquela se volta "para a vida deles não só no sentido da sua defesa mas também no do seu desenvolvimento, da sua potenciação, da sua maximização". Logo, se a biopolítica "solda, aumenta, estimula", o poder soberano "tolhia, refreava, até aniquilar."

O direito de vida e de morte foi, no decorrer de muitos séculos, de acordo com Foucault (1999), um privilégio inerente à soberania como derivação da antiga patria potestas, que consistia no poder de disposição concedido ao pai em relação à vida dos filhos e dos escravos. O direito sobre a vida e a morte dos súditos, porém, na visão foucaultiana (1999), é possibilitado somente nos casos em que o soberano se encontre ameaçado em sua existência. 
O velho direito de morte - que representa a institucionalização estatal da antiga concepção da patria potestas - consiste na decisão do soberano de quem deve morrer e, por consequência, de quem merece viver. O ponto crucial, diante disso, está no poder incutido na soberania de provocar a morte, razão pela qual a vida é um mero resultado do não exercício do direito de matar, isto é, faz-se morrer, mas, caso não o faça, deixa-se viver.

A vida e a morte, à luz desse horizonte, somente alcançam o status de direitos aos súditos no momento em que há uma decisão soberana. Isso porque, na concepção de Foucault (2005, p. 286), os súditos, com base no direito, não são nem vivos e nem mortos, mas, sim, neutros, haja vista que "é simplesmente por causa do soberano que o súdito tem direito de estar vivo ou tem direito, eventualmente, de estar morto".

A importância da vida do súdito somente mostra-se, assim, no instante em que recebe do soberano o direito de estar vivo. Trata-se, em certa medida, de uma constante ameaça, cuja vida, na omissão do soberano, se encontra validada, uma vez que a ação, em tese, age em prol da morte, com o que o detentor da soberania extravasa, então, a irrelevância daquela vida para a sociedade e, também, para si.

A teoria foucaultiana (1999), no entanto, caracteriza o direito de vida e de morte como referente ao soberano, essencialmente em virtude de existirem motivos causadores do ceifar da vida. Assim, consoante Ayub (2015, p. 58), "o direito de matar aparece ao poder soberano como forma de castigo ou retaliação àqueles que ousam contra a Lei, o que, em última instância, é o mesmo que romper com o pacto fundador do próprio poder de soberania”.

$\mathrm{O}$ adestramento dos corpos e as regulações da vida, no entanto, rompem com o paradigma de fazer morrer e deixar viver. O objetivo de tornar os indivíduos dóceis, úteis e saudáveis desencadeia a necessidade de um poder, agora, de fazer viver e deixar morrer. Esta mutação delineou uma alternância da soberania porque representou, segundo Foucault (2005), a assunção da vida nos mecanismos e nos cálculos do poder.

De acordo com a filosofia foucaultiana $(1999$, p. 128) e atinente ao direito e ao dever de fazer viver e deixar morrer:

Surgiu um poder destinado a produzir forças, a fazê-las crescer e a ordená-las mais do que a barrá-las, dobrá-las ou destruí-las. Com isso, o direito de morte tenderá a se deslocar ou, pelo menos, a se apoiar nas exigências de um poder que gere a vida e a se ordenar em função de seus reclamos. Essa morte, que se fundamentava no direito do soberano se defender ou pedir que o defendessem, vai aparecer como o simples reverso do direito do corpo social de garantir sua própria vida, mantê-la ou desenvolvê-la. 
Os novos mecanismos do poder, essencialmente vinculados a uma biopolítica da população, ocasionaram a modificação do direito de soberania - significativamente atrelado à decisão sobre a morte - a um direito de zelo à vida. Contudo, conforme Foucault (2005, p. 287), isso não corresponde à eliminação e à substituição dos contornos da velha soberania - fazer morrer e deixar viver - e, sim, à conformação de um direito - fazer viver e deixar morrer - que "vai penetrá-lo, perpassá-lo, modificá-lo".

A par desse novo cenário, no qual se calca o poder moderno e contemporâneo, Ayub (2015) assevera que a função central de valorizar a vida torna impotente a outrora e essencial atribuição soberana de morte, pois o interesse essencial da biopolítica é o investimento sobre a vida. Todavia, houve, na esteira foucaultiana (2005), o desenvolvimento de um mecanismo estatal de justificação da morte em prol da melhoria da vida, qual seja: o racismo.

Para Foucault (2005), o racismo existia antes mesmo da assunção da biopolítica, mas foi a emergência do biopoder que o inseriu no seio do Estado como fundamento do poder. A partir da Modernidade, deste modo, utiliza-se do racismo, em certas situações e em determinados limites, com o fim de atingir, por meio da morte de algumas populações, aos objetivos inerentes a uma política exercida sobre a vida biológica de outras populações.

Assim, no seio de uma sociedade alicerçada no biopoder, o racismo, na definição foucaultiana (2005, p. 306), "é indispensável como condição para poder tirar a vida de alguém, para poder tirar a vida dos outros". Isso significa, segundo Ayub (2015, p. 109), que "o racismo é o mais novo disfarce com o qual entra em cena o poder de soberania", ou seja, o direito de matar, mas que, nos liames atuais, atua estrategicamente com vistas a fazer viver.

O racismo, na visão de Foucault (2005), constitui-se de duas funções: a primeira delas está ligada à divisão daqueles que devem viver e daqueles que devem morrer, ao passo que a segunda delas está vinculada à noção de melhoria da vida de alguns por meio da morte de outros. Neste ponto, pois, situa-se o paradoxo que vincula o antigo direito soberano de matar ao atual direito sobre a vida.

A primeira razão de existir do racismo diz respeito, então, à cesura do âmbito biológico no qual se realiza o biopoder. Na lição de Foucault (2005), a divisão social entre raças capaz de hierarquizá-las a ponto de algumas serem consideradas superiores às outras garante uma fragmentação do contínuo biológico envolvente do poder, a fim de promover a defasagem de alguns grupos em privilégio de outros.

Trata-se, a bem da verdade, da cisão da espécie humana em grupos considerados matáveis e grupos considerados privilegiados, isto é, destinatários, de um lado, de uma política 
de morte e, de outro lado, de uma política de desenvolvimento e fortalecimento da vida. Esta cesura biológica é o elemento para a concretização da segunda função do racismo, que tem a morte de alguns, justamente, como meio de favorecimento da vida de outros.

A segunda atribuição do racismo refere-se, consoante Foucault (2005, p. 305), a uma relação de guerra sob contornos biológicos, o que se exterioriza na seguinte expressão: "se você quer viver, é preciso que o outro morra". A morte do outro é favorável e necessária em uma estrutura biopolítica, pois, conforme Ayub (2015), o investimento sobre a vida corrobora a eliminação das raças impuras com o objetivo de purificar as raças superiores.

Desse modo, a relação racista entre a necessidade da morte para a melhoria da vida pode ser retratada, na teoria foucaultiana (2005), sob a perspectiva de que o desaparecimento das espécies vistas como inferiores, anormais e degeneradas produzirá a força, o vigor e a proliferação das espécies consideradas superiores. Nesse sentido, a morte da raça ruim permitirá uma vida mais sadia e pura à humanidade em geral.

A elevação da vida como objeto e instrumento do poder, principalmente a partir dos séculos XVII e XVIII, tem o seu fundamento centrado, em tese, em prol dos controles e das regulações da vida, fazendo-a, inclusive mediante o uso de disciplinas, dócil e útil. Contudo, para Foucault (2005), o velho direito de matar mantém-se presente por meio do racismo de Estado e se nota direcionado, essencialmente, embora com a promoção de morte, a fazer viver - norte da biopolítica.

A vida, na análise de André Duarte (2008), constitui-se, em um contexto tal, como elemento político por excelência, mas tal constatação não minimizou a violência, e, sim, trouxe a necessidade crescente da morte em escala massificada em prol de melhores condições de sobrevivência a um certo grupo populacional. Isso corrobora, pois, a visão de compatibilidade do uso da morte em uma política estatal de zelo pela vida.

Por isso, no âmago de uma sociedade marcadamente biopolítica, na qual reina o interesse de fazer viver e deixar morrer, a vida somente pode ser ceifada se visar, a teor da lição foucaultiana (2005, p. 306), à “[...] eliminação do perigo biológico e ao fortalecimento, diretamente ligado a essa eliminação, da própria espécie ou da raça". Logo, o antigo direito de matar é reduzido, da Modernidade até hodiernamente, a situações ensejadoras de benefícios à vida - de parcela - da espécie humana.

Para Foucault (2005), no entanto, a definição de tirar a vida de certas coletividades não se vincula apenas ao assassínio direto, mas, também, ao que pode ser identificado como assassínio indireto, a exemplo de expor à morte, de multiplicar o risco de morte ou, ainda, de 
provocar a morte política, a expulsão e a rejeição. Trata-se, aliás, de oportunizar, embora não diretamente, a eliminação de certos grupos - ou raças - humanos.

Constata-se, portanto, que há duas formas de prática do poder emergidas a partir dos séculos XVII e XVIII: anátomo-política e biopolítica. Ambas, na lição de Foucault (2005), não se excluem, mas, sim, se complementam e se referem à alternância da clássica concepção do poder soberano de fazer morrer e deixar viver para, agora, fazer viver e deixar morrer, não obstante o racismo seja uma justificação da possibilidade de matar alguns com a ambição de favorecer a vida de outros.

A partir do exposto, tem-se como relevante a análise da inserção histórica e concreta do racismo estatal na política contemporânea relacionada ao controle da criminalidade, haja vista que o processo penal, a execução criminal e a violência apresentam contornos de segregação racista no Estado brasileiro no tocante à população negra. Cuida-se de averiguar a seguir, então, a seletividade racial como retrato do contingente populacional criminalizado e/ou destinatário da ação delitiva no Brasil.

\section{PERSECUÇÃO PENAL E VIOLÊNCIA: A COR QUE IMPORTA}

As luzes da Modernidade e o florescer da Contemporaneidade assentaram o racismo como instrumento institucional e social destinado ao combate da criminalidade. O processo penal e a execução criminal, como meios de averiguação e sanção àqueles que transgridam os mandamentos legais, bem como a violência, constituem-se atualmente como espaços jurídicopolíticos de alastramento da ideia de raças e de desvelamento da biopolítica.

Os delineamentos históricos em torno da concepção de raças puras e impuras, boas ou ruins, protegidas ou matáveis, relacionam-se ao plano de fundo do romance norte-americano, mas de temática e alcance mundial, O sol é para todos, de Harper Lee, lançado em 1960. Tais evidências, aliadas aos informes estatísticos sobre o encarceramento e a violência no Brasil, autorizam uma análise aguçada e necessária acerca do racismo instituído no País.

O racismo incutido nas instituições e como mecanismo, inclusive, de controle social remonta à constituição histórica da sociedade e do poder. A tese foucaultiana (2005), aliás, assegura o início do desenvolvimento do racismo com a colonização de terras, essencialmente em virtude de a práxis do biopoder exigir uma razão de ser para a possibilidade de matança de populações e de civilizações. 
A colonização, como é o retrato da relação estabelecida entre a Europa com a América Latina, firmou uma ideologia internacionalmente hegemônica de superioridade dos brancos e de inferioridade dos negros. A partir disso, a formação cultural, econômica, política e social dos territórios desbravados, a exemplo do Brasil, é o resultado da herança colonizadora que se encontra, ainda, inserida nos mais diversos segmentos públicos e privados.

Tal cenário, à luz da biopolítica, é perceptível e inteligível porque o biopoder, na visão de Foucault (1999), representa um sistema elementar para a ascensão e para o progresso do capitalismo, cujos instrumentos de controle e regulação possibilitaram o desenvolvimento de meios de segregação e hierarquização social. A separação e a qualificação de certos grupos, ou raças, em hierarquias, mostraram-se necessárias para a consolidação de uma conjuntura organizacional de dominação.

Nesse sentido, a complexidade envolvente do biopoder oportunizou, sobremaneira, as relações capitalistas, como é o caso dos processos coloniais, haja vista que, consoante a teoria foucaultiana (1999, p. 133), permitiu o “[...] ajustamento da acumulação dos homens à do capital, a articulação do crescimento dos grupos humanos à expansão das forças produtivas e a repartição diferencial do lucro [...]”".

A busca de novos territórios e o incremento das relações de domínio, com ações e discursos firmados, substancialmente, no seio da burguesia e do capitalismo, promoveram, nos séculos XIX e XX, segundo Hannah Arendt (2017a), o fenômeno do imperialismo. Trata-se de uma política de expansão oriunda do colonialismo e provocada pela incompatibilidade do sistema de Estados nacionais com o desenvolvimento econômico e industrial.

A concepção de raça, na vertente arendtiana (2017a), foi elevada ao grau de princípio da estrutura política como fundamento para a ascensão do imperialismo e da conquista de terras ocupadas por indivíduos considerados não-civilizados. Os povos locais, a exemplo da colonização europeia em solos latino-americanos, como é o caso dos nativos brasileiros, eram, assim, vistos, consoante Arendt (2017a), como grupos sem culturas ou histórias próprias.

A raça foi utilizada, dessa forma, de acordo com a filosofia arendtiana (2017a), com o intuito de explicar a existência de seres humanos com características físicas, como as feições, diversas das dos homens brancos e, consequentemente, estranhas ao entendimento dos europeus. Estes buscaram, então, na raça um modo de manifestar, a teor de Arendt (2017a), os seus desejos de não pertencimento à mesma espécie humana.

Além disso, na lição arendtiana (2017a), a cor da pele não era concebida como o único elemento da raça, senão, isto sim, o fato de os seres humanos, vislumbrados como estranhos, 
viverem como se integrassem a natureza e, logo, não tivessem construído um mundo humano. Esta noção de "animalidade", conforme Arendt (2017a), conduziu à situação de o massacre e o extermínio desses indivíduos não terem sido considerados como um delito efetivado contra homens - ou melhor, seres humanos.

A violência escancarou-se nas relações coloniais tardo-modernas com a nivelação das raças. Para Achille Mbembe (2016, p. 134), “o direito soberano de matar não está sujeito a qualquer regra nas colônias", pois nestes territórios dominados "o soberano pode matar em qualquer momento ou de qualquer maneira"5. Trata-se, com efeito, da retratação clarividente do exacerbamento do racismo estatal frente às camadas racialmente selecionadas, com ênfase à população negra.

A partir disso, com base na manutenção - mitigada - do direito soberano de matar em uma sociedade de viés biopolítico, Claude Lévi-Strauss (2005, p. 212) idealiza a conceituação de racismo:

Um: existe uma correlação entre o patrimônio genético de um lado, as aptidões intelectuais e as disposições morais de outro. Dois: esse patrimônio, de que essas aptidões e disposições dependem, é comum a todos os membros de alguns grupos humanos. Três: esses agrupamentos chamados "raças" podem ser hierarquizados em função da qualidade de seu patrimônio genético. Quatro: as diferenças autorizam as "raças" ditas superiores a comandar, a explorar as outras, eventualmente destruí-las.

O fator biológico e suas correlações são, assim, centrais à configuração do racismo. A definição das raças superiores ou inferiores é válida no âmbito da biopolítica, pois oportuniza a edificação de hierarquias institucionais e sociais e o estabelecimento das classes passíveis de assassínio direto ou indireto. Tal conformação é evidente, com supedâneo na diferenciação a partir da cor da pele, na conjuntura envolvente do processo penal, da execução criminal e da violência em relação à população negra.

A inserção e a difusão do racismo no território brasileiro são frutos históricos, mas sem desconsiderar outros fatores, da colonização realizada pelos europeus. A superioridade da metrópole em detrimento da colônia fez emergir uma sociedade dividida, tanto fática quanto simbolicamente, em raças. Na seara da cor da pele, isto se mostra notório entre, de um lado, os brancos, como a raça boa, e, de outro lado, os negros, como a raça ruim.

\footnotetext{
5 A excessiva cifra de mortes, contabilizadas na sociedade contemporânea, como resultado da maximização da interferência do Estado ou, também, da minimização de sua atuação em áreas necessárias conduz Achille Mbembe (2016) a considerar a transgressão da biopolítica, ou biopoder, em necropolítica, ou necropoder. Essa nova definição, arraigada em múltiplos episódios violentos, decorre da submissão de inúmeros seres humanos a situações extremas e conferidoras da condição de "mortos-vivos" (MBEMBE, 2016, p. 146). Não se estaria mais em uma era de valorização da vida, mas, sim, em uma era de intensificação da morte.
} 
Diante disso, o racismo, consoante David Williams e Naomi Priest (2015), manifestase em duas órbitas, quais sejam: por meio de indivíduos e por meio de instituições, além de se fundar em preconceito, estereótipo e discriminação de grupos étnico-raciais estigmatizados. $\mathrm{O}$ caso brasileiro é retrato sólido desta ideia de superioridade dos brancos e de inferioridade dos negros incutida nas várias dimensões institucionais e sociais.

A classificação dos indivíduos em raças é fruto da era moderna. Para Silvio Almeida (2019), a idealização de raça consiste em um episódio surgido em meados do século XVI, enquanto as teorias deterministas raciais, conforme Lilia Moritz Schwarcz (2018), emergem em torno do século XVIII, mas, antes de ser relacionado à biologia, o termo comportava a noção de conjuntos de pessoas vinculadas a uma origem comum, sem um cariz natural.

As teorias raciais foram recepcionadas no Brasil do século XIX concomitantemente à ascensão do movimento abolicionista destinado a encerrar os mais de trezentos anos de escravidão. Apesar da ausência de dados sólidos, a escravidão brasileira, abolida com a Lei Áurea em 13 de maio de 1888, teria recebido 3,6 milhões de africanos (SCHWARCZ, 2018). Com o fim do trabalho escravo, milhares de homens e mulheres tornaram-se livres e iguais, embora tão só formalmente.

Com efeito, o critério racial foi adotado com o intuito de selecionar e deteriorar - ou qualificar - a figura de certas categorias (SCHWARCZ, 2005). Logo, a raça, nos termos de Schwarcz (2018, p. 34), deve ser considerada “como uma construção local, histórica e cultural que tanto pertence à ordem das representações sociais [...] como exerce influência real no mundo, por meio da produção e reprodução de identidades coletivas e de hierarquias sociais politicamente poderosas".

Há, no Brasil, a formação e a manutenção do racismo estrutural. Isso ocorre, na lição de Almeida (2019, p. 50), em virtude de o racismo encontrar-se incutido na sociedade e nas instituições, razão pela qual "o racismo é uma decorrência da própria estrutura social” dada a normalidade, em certa medida, "com que se constituem as relações políticas, econômicas, jurídicas e até familiares, não sendo uma patologia social e nem um desarranjo institucional".

A inserção dos caracteres raciais no Estado somente evidencia o resultado de uma ideologia difusa no tecido societal. Assim, a instituição estatal coloca em marcha o racismo, pois, sem o Estado, o racismo não teria viabilidade de se reproduzir e se retroalimentar, posto que, por intermédio dele, "a classificação de pessoas e a divisão dos indivíduos em classes e grupos é realizada" (ALMEIDA, 2019, p. 89). 
Insta salientar, no entanto, que a divisão social em raças não é exclusiva de uma ou outra nação, mas, sim, elemento corriqueiro que transpassa os limites fronteiriços. Nesse sentido, o livro $O$ sol é para todos, de Harper Lee, um dos maiores clássicos do romance norte-americano escrito no início da segunda metade do século XX, é importante para uma reflexão acerca da influência social do racismo no âmbito do processo penal.

A pertinência da sobredita obra literária decorre da similitude dos casos estadunidense e brasileiro. As prisões dos Estados Unidos da América (EUA) abrigam o maior contingente de segregados do mundo. O Brasil situa-se em terceiro lugar no ranking mundial de reclusos. Ambos notabilizam, assim, o encarceramento em massa resultante da adoção de teorias como "lei e ordem" e "tolerância zero", cuja essência encontra-se na estratificação racial.

A segunda metade do século XX revelou a ascensão de medidas austeras no combate à - seletiva - criminalidade. O fenômeno, que se esboçou e se materializou nos EUA, alastrouse pelo mundo e invadiu, também, o Brasil, mesmo que, àquela época, o País vivenciasse a luta pela retomada da democracia e pela afirmação de direitos humanos. As chamadas "lei e ordem" e "tolerância zero" evidenciam a modificação do foco do Estado no enfrentamento do crime e do criminoso.

Tem-se, com efeito, a intensificação do controle. Isso repercute, a teor de Jock Young (2002, p. 62), em acréscimo numeral, embora não se relacione, necessariamente, à taxa real de crimes, senão, isto sim, sobretudo, às respostas institucionais e sociais à dita criminalidade, "às vezes representadas como cortinas de fumaça para os interesses investidos do sistema de justiça criminal, e outras como metáforas de ansiedades sociais mais amplas, não relacionadas à criminalidade".

O sistema de justiça penal constitui-se como a porta de entrada da hierarquização dos seres humanos tanto nos EUA como no Brasil. As leis não diferenciam os indivíduos. Porém, na esteira de Michelle Alexander (2018, p. 36), as castas raciais não foram extintas nos EUA, pois "nós apenas as remodelamos". Neste sentido, o sistema de justiça penal exibe-se como subterfúgio à marginalização racial. O mesmo ocorre no Brasil atual, embora na contramão da Constituição Federal de 1988. Logo, ratifica-se a utilização do referido texto literário.

A trama, narrada por uma criança, ocorre em Maycomb County, Alabama, nos EUA, e envolve uma série de acontecimentos do cotidiano de dois irmãos e um amigo na vila onde residem. O ponto crucial a ser discutido, porém, concerne à teia elementar da obra em relação à desigualdade racial e às interferências dessa cultura de não aceitabilidade da diferença na 
seara processual no instante em que um dos personagens, de pele negra, é acusado de estupro (LEE, 2018).

O advogado Atticus Finch, pai dos irmãos Jeremy e Jean Louise Finch, foi nomeado pelo magistrado Taylor para atuar na defesa do réu Tom Robinson. Tratava-se de um alegado caso de estupro, no qual a suposta vítima, Mayella Violet Ewell, de pele branca, teria sido violentada na sua casa. O pai de Mayella, Bob Ewell, teria visto a cena e chamado o xerife Heck Tate, que prendeu o acusado (LEE, 2018).

A partir dessa história, o racismo mostra-se constante na trama. Vários personagens acusam o advogado de "amigo dos negros". As crianças, não entendendo o rótulo criado, indagam ao pai, que responde: “- Scout - disse o Atticus - 'amigaço dos negros' é uma daquelas expressões que não significa nada [...] Só as pessoas ignorantes e más é que a usam quando pensam que alguém está favorecendo mais os negros do que a elas próprias" (LEE, 2018, s. p.).

A face do racismo, contudo, não se restringiu ao ambiente familiar e social. Na sessão de julgamento, o pai da alegada vítima, ao prestar depoimento, afirmou: “[...] Eu sabia quem era, e que vivia lá naquele ninho de pretos qu' tod'os dias passavam lá por casa. Ó juiz, há quinze anos que peço a este condado p'ra limpar aquele ninho, qu'inté é perigoso viver ao lado deles e p'ra'lem disso desvaloriza a minha propriedade..." (LEE, 2018, s. p.).

A afirmação do pai da suposta vítima comprova, pois, a intencionalidade socialmente disseminada de exclusão - como exemplo do assassínio indireto trazido na tese foucaultiana da população negra. A aspirada separação geográfica entre brancos e negros pode ser vista, nesse sentido, como fator econômico a vir a beneficiar a produtividade daqueles que ostentam biologicamente o status de brancos.

Ademais, o acusado, no seu interrogatório, foi indagado pelo seu advogado quanto ao motivo de ter fugido da casa da alegada vítima no instante em que o pai dela teria se aproximado. O diálogo travado foi o seguinte:

- E então você fugiu?

- Sim, sinhô.

- Por que fugiu?

- Estava com medo, sinhô.

- De que é que tinha medo?

- Sr. Finch, se o sinhô fosse preto com'eu tamém tinha medo. (LEE, 2018, s. p.).

A dicotomia entre brancos e negros, entre a raça superior e a raça inferior, dessa forma, é nítida no desenrolar da obra. Tal situação manteve-se na decisão dos jurados, em que pese o discurso defensivo e realista dos fatos - a fim de demonstrar a inocência do acusado - apontasse 
e comprovasse que o réu não dispunha de forças na mão esquerda, por ser "aleijado", e o pai da suposta vítima - que foi agredida, de frente, no lado direito - fosse canhoto (LEE, 2018).

A sentença condenatória, embora passível de recurso, manteve o réu preso a anteceder o cumprimento da imposta pena capital. $\mathrm{O}$ acusado, no entanto, ciente da sua condição de negro e, logo, de um sujeito a quem o direito não se aplica em seu benefício, resolveu fugir do estabelecimento de custódia. Na fuga, após os guardas terem solicitado que parasse, Tom Robinson morreu com 17 tiros (LEE, 2018).

A conversa do advogado e sua irmã, Alexandra Finch, demonstra nitidamente, mais uma vez, a função da cor da pele como elemento característico de um direito, sob contornos biopolíticos, que se aplica à morte ou à vida:

- [...] Dezessete buracos de balas. Não era preciso disparar tanto. [...]

- Esta foi a última gota, Atticus - disse a tia Alexandra.

- Depende da perspectiva - disse ele.

- O que é um negro a mais ou a menos no meio de duzentos? Para eles, ele não era o Tom, era apenas um fugitivo. (LEE, 2018, s. p.).

A par disso, constata-se que a cor da pele influi substancialmente na importância que se dá a ela em prol da vida ou da morte dos indivíduos, inclusive no âmbito das instituições estatais vinculadas à função da justiça. O sentimento de racismo impregnado institucional e socialmente, mediante, de acordo com Maria Helena Rodrigues Navas Zamora (2012), desigualdades culturais, políticas, psicológicas e sociais, legitima as diferenças com escopo nas alegadas distorções biológicas das raças.

Uma situação equivalente à narrada na literatura fictícia de $O$ sol é para todos, com foco no processo penal, é evidenciada nos informes estatísticos de encarceramento no Brasil. Os números demonstram a segregação definida de uma cor, o que exterioriza o aparato policial, emanado do Estado, com subsídio, quiçá, em uma política racista de exclusão ou eliminação do convívio social de negros.

O supramencionado cenário é constatado no Levantamento Nacional de Informações Penitenciárias - Período de Janeiro a Junho de 2020. O referido documento contabiliza que o contingente prisional brasileiro é de 702.069 presos (BRASIL, 2021) ${ }^{6}$. A cifra em tela exibe,

\footnotetext{
${ }^{6}$ A população prisional brasileira aumenta continuamente. Em 1990, havia 90 mil presos; em 1992, 114,3 mil; em 1993, 126,2 mil; em 1994, 129,2 mil; em 1995, 148,8 mil; em 1997, 170,6 mil; em 1999, 194,1 mil; em 2000, 232,7 mil; em 2001, 233,8 mil; em 2002, 239,3 mil; em 2003, 308,3 mil; em 2004, 336,3 mil; em 2005, 361,4 mil; em 2006, 401,2 mil; em 2007, 422,3 mil; em 2008, 451,4 mil; em 2009, 473,6 mil; em 2010, 496,2 mil; em 2011, 514,5 mil; em 2012, 549,7 mil; em 2013, 581,5 mil; em 2014, 622,2 mil; em 2015, 698,6 mil; em 2016, 722,1 mil; em 2017, 722,7 mil; em 2018, 744,2 mil; e, em 2019, 755,2 mil (BRASIL, 2021).
} 
no entanto, a predominância de pardos/pretos com o percentual de 66,31\%, juntamente com branca $(32,52 \%)$, amarela $(0,98 \%)$ e indígena (0,19\%) (BRASIL, 2021).

A desproporcionalidade de reclusos no tocante à raça, cor ou etnia entre as unidades federativas também chama a atenção, embora se vincule, em maior ou em menor grau, à distribuição de pardos/pretos no território nacional. De um lado, a Bahia conta com a maior concentração percentual de pardos/pretos na prisão, com 93,05\%; de outro lado, o Rio Grande do Sul possui a menor presença percentual de pardos/pretos na prisão, com 32,60\% (BRASIL, 2021).

Apesar da relevância dos supraditos números, a situação mais acentuada e alarmante é retratada e, aliás, confirmada pelo Atlas da Violência, produzido pelo Instituto de Pesquisa Econômica Aplicada (IPEA, 2020). Faz-se viável extrair do referido documento os dados atinentes à violência perpetrada em face da população negra no País, cujos índices ratificam a seletividade examinada neste estudo.

O Atlas da Violência, com referência ao ano de 2018, informa que a taxa de homicídios de pardos/pretos, a cada 100 mil habitantes, foi de 37,8, enquanto a de brancos, amarelos e indígenas foi de 13,9. Mais surpreendentemente: no ínterim de 2008 a 2018, a taxa de assassinatos do primeiro grupo cresceu 11,5\%, ao passo que, no tocante ao segundo grupo, diminuiu 12,9\% (IPEA, 2020).

Em relação aos Estados-membros, Roraima (87,5), Rio Grande do Norte (71,6), Ceará $(69,5)$, Sergipe $(59,4)$ e Amapá $(58,3)$ tiveram, a cada 100 mil habitantes, as maiores taxas de assassinato de pardos/pretos. As menores taxas foram registradas em São Paulo $(9,8)$, Santa Catarina (12,6), Paraná (17,7), Minas Gerais $(19,9)$ e Piauí (20,3). As estatísticas mencionadas do Atlas da Violência alusivas a 2018 demonstram, então, a excessiva vulnerabilidade desta raça, cor ou etnia no Brasil (IPEA, 2020).

Os números acima descritos demonstram, com efeito, na leitura de Danilo de Souza Morais e Jacqueline Sinhoretto (2018), o aumento da disparidade racial no decorrer do atual século XXI e a acentuação do racismo institucional como refreio aos pardos/pretos mediante a morte e o encarceramento. A violência é o desiderato de ações e discursos estruturais com assento na história do Brasil.

Em estudo com dados de 2008 a 2012, Jacqueline Sinhoretto, Giane Silvestre e Maria Carolina Schlittler (2014) analisaram as prisões em flagrante no Estado de São Paulo. Com atenção ao critério de raça, cor ou etnia, 54,1\% dos detidos eram negros, sendo de 35,0 a cada 
100 mil habitantes a taxa de negros maiores de 18 anos. No tocante à taxa de brancos maiores de 18 anos presos em flagrante, a cifra atingiu o número de 14 a cada 100 mil habitantes.

Nesse sentido, Sinhoretto, Silvestre e Schlittler (2014, p. 25) destacam que:

[...] os dados apontam maior vigilância policial sobre a população negra, que se reflete na concentração do número de prisões em flagrante sobre este grupo. Este tipo de prisão não decorre de uma investigação criminal prévia, executada por meio de mandado judicial, sendo muito mais recorrente em casos de abordagem policial. Os dados indicam que, no cometimento de delitos, os negros são flagrados com maior frequência do que brancos, pois são mais visados pela ação policial.

Tais dados ratificam o fato de que ser negro, no Brasil, faz com que automaticamente o indivíduo seja colocado em uma esfera de maior suspeição no que diz respeito às abordagens pelos órgãos responsáveis pela segurança pública. À margem da evolução, no Brasil ilustrado pelo viés da "terra da democracia racial, do senso comum ao formalismo acadêmico, circula, há muito, a percepção de que o sistema se dirige preferencialmente ao segmento negro da população" (FLAUZINA, 2008, p. 40).

A sociedade é levada, na visão de Juliana Borges (2019, p. 86), a "acreditar que o sistema de justiça criminal surge para garantir normas e leis que assegurarão segurança para seus indivíduos", quando, na verdade, constitui um aparelho que, desde o seu nascer, "cria o alvo que intenta reprimir". É possível vislumbrar, então, a compleição seletiva do público, a um, que será criminalizado e do público, a dois, que será protegido em seus bens jurídicos.

Assim, Eugenio Raúl Zaffaroni e José Henrique Pierangeli (2002, p. 58) advertem acerca da existência de "um processo de seleção das pessoas às quais se qualifica como 'delinquentes' e não, como se pretende, um mero processo de seleção das condutas ou ações qualificadas como tais". Por isso, o discurso jurídico anda em descompasso com as suas reais externalidades, notadamente porque "o sistema penal se dirige quase sempre contra certas pessoas mais que contra certas ações” (ZAFFARONI; PIERANGELI, 2002, p. 70).

O aparelho repressivo-punitivo do Estado é conduzido, assim, a locais e a grupos da população previamente definidos por escolha política, conforme Camila Caldeira Nunes Dias (2017). Se a instituição estatal encarregada de controlar, vigiar e sancionar os transgressores da almejada ordem social atuar em campos específicos, consoante Alessandro Baratta (2018), o resultado é a identificação de um feitio de crime e de criminoso, sem que, necessariamente, corresponda à criminalidade em sentido lato a ser combatida.

A partir disso, no Brasil, o sistema de justiça penal "segue direcionando o seu aparato repressivo e violento", ainda no século XXI, especialmente, "sobre os espólios da escravidão" 
(WERMUTH, 2018, p. 292). Para esta camada do tecido societal, há tão só uma resposta: “a segregação, tanto pela via da marginalização social e espacial quanto por meio do encarceramento em massa e da eliminação pura e simples a partir da intervenção violenta do sistema punitivo" (WERMUTH, 2012, p. 238). Materializa-se, com efeito, o racismo.

O racismo, como mecanismo de realização do velho direito soberano de matar no seio de uma sociedade regida pela biopolítica, notabiliza-se nas esferas do processo penal, da execução criminal e da violência. Os negros, como população preferida na condição de vítimas de homicídio e de clientes do sistema carcerário nacional, comprovam que a cor da pele importa para a seleção que se faz dos que têm direito a viver ou, caso contrário, a morrer.

A tese foucaultiana (2005), à vista do exposto, considera o racismo como a prática do assassínio direto e indireto. No caso dos negros, a irrelevância de suas vidas é representada em dois polos, nos quais se pode, ou não, ver o sol nascer: de um lado, a vida propriamente ceifada; de outro, a vida excluída do tecido societal. Os contornos e as configurações dessa vida, embasada a partir da cor da pele, na sociedade contemporânea, é o que se reflete a seguir com base na teoria filosófica agambeniana.

\section{HOMO SACER E VIDA NUA: A EXCLUSÃO QUE INCLUI OS NEGROS}

O racismo é a construção de um mecanismo de seleção e de exclusão das vidas consideradas impuras, ruins, perigosas e desnecessárias. O Estado, no instante em que o fator biológico dos corpos assumiu o papel central da política, precisou encontrar um subterfúgio para a justificação das mortes antes atribuídas ao poder soberano. A atualidade é, a partir disso, um espaço temporal destinado a fazer viver, mas, inclusive, sob o manto de matar.

Um cenário, nos termos anteriormente descritos, resulta da célebre constatação de Foucault (1999, p. 134): “O homem, durante milênios, permaneceu o que era para Aristóteles: um animal vivo e, além disso, capaz de existência política; o homem moderno é um animal, em cuja política, sua vida de ser vivo está em questão". É a própria vida, ou morte, do ser humano que se torna objeto e instrumento do poder.

O modo de operação do biopoder, nesse sentido, segundo Duarte (2008), consiste no legado foucaultiano em torno da produção e do incentivo calculado e administrado da vida de certa população, passível, até mesmo, de provocar o genocídio de determinados corpos em benefício de outros. A seleção das vidas a serem assassinadas, seja direta, seja indiretamente, depende do racismo, o qual encontra na cor da pele uma das suas várias características. 
O dilema contemporâneo assenta-se, pois, em desvendar as vidas que importam, ou não, para o poder constituído e para a sociedade. Tal reflexão, neste século XXI, é possível à luz dos escritos de Giorgio Agamben, cuja obra, na visão de Duarte (2008), relaciona definições elementares da (bio)política ocidental sintetizadas em poder soberano, vida nua, estado de exceção e campo.

A biopolítica, na filosofia agambeniana, porém, conforme Peter Pál Pelbart (2011), não é, como traz a análise foucaultiana, fruto e vivência exclusivos da Modernidade, mas, sim, um instituto já existente nas sociedades e nos círculos do poder desde a Antiguidade. Uma afirmação assim é possível à luz da figura do homo sacer, que remonta ao direito romano arcaico e se mostra atual quando confrontada com a presente conjuntura política.

O homo sacer, de acordo com Agamben (2007), refere-se a um personagem clássico a quem se imputa o cometimento de certo delito, cuja sanção consiste em tornar o sujeito criminoso matável e insacrificável. Trata-se, assim, de um lado, de uma vida matável, sem que o homicídio do homo sacer seja punido, e, de outro lado, uma vida insacrificável, pois não pode ser entregue como sacrifício aos deuses.

A par disso, a tese agambeniana (2007) sustenta o homo sacer como detentor de uma vida sacra ambivalente. Isso porque, segundo Agamben (2007), o homem sacro, por ser matável, encontra-se fora da jurisdição humana e, por ser insacrificável, localiza-se fora da jurisdição divina, a ponto, diante disso, de situar-se excluído de ambas as zonas e, via de consequência, manter-se em um espaço de indistinção.

O homo sacer, assim, na interpretação de Castor Mari Martín Bartolomé Ruiz (2012, p. 4), acha-se "incluído pela exclusão e excluído de forma inclusiva". O paradoxo aqui apresentado consiste na exclusão de direitos ao homem sacro e, logo, desprovido de uma constituição jurídico-política, ao mesmo tempo em que o abandono à violência e à violação o inclui naquilo que a filosofia agambeniana (2007) denomina de bando.

O bando exterioriza-se como o resultado da seletividade biopolítica. Cuida-se de um grupo, cuja característica e formação são de seres humanos abandonados ou, ainda, bandidos. Uma inclusão tal, oriunda de uma exclusão, pode, aliás, ser vista à luz do racismo perpetrado tanto institucional quanto socialmente em relação à cor da pele. Ora, é a própria vida excluída de direitos humanos e, por conseguinte, de proteção enraizada na população negra no Brasil.

Os números - apontados na seção precedente - indicam a múltipla violência a que os negros se encontram submetidos na Contemporaneidade. A cor do cárcere, como sinônimo de exclusão da vida social, mas, também, de inclusão na relação de bando, e a morte de negros, 
como representação direta da eliminação da raça impura, ruim, perigosa e desnecessária, são elementos consistentes de uma seletividade biopolítica de homines sacri pela cor da pele.

Ademais, consoante Ruiz (2012, p. 6), os “banidos são bandidos porque foram expulsos da ordem e sobre eles se decretou uma exclusão inclusiva que os tornou vida nua". O processo penal e a execução criminal fundamentam-se em uma almejada garantia de ordem, por meio da qual, para ser realizada, é necessário retirar do convívio em sociedade aqueles grupos considerados prejudiciais. Esta exclusão-inclusão constrói as vidas nuas.

A vida nua é a expressão utilizada por Agamben (2007) para definir a vida despida de qualquer proteção e, via de consequência, destituída do seu estatuto jurídico-político junto ao Estado. A reflexão calca-se na clássica distinção grega entre zoé e bíos ou, respectivamente, entre a mera vida existencial e a vida qualificada, na qual a primeira diz respeito ao ambiente privado (casa) e a segunda refere-se à vida sociopolítica (cidade).

A Modernidade, contudo, trouxe como inovação, à luz da biopolítica, a conformação de zoé, segundo Edgardo Castro (2012), como objeto da política. Nesse diapasão, a instituição estatal utiliza da vida natural, e não da bíos, como elemento norteador do exercício do poder, o que se encontra defendido por Arendt (2007) ao proclamar que o centro da política moderna é a simples vida biológica.

A contribuição de Ruiz (2012, p. 9), no mesmo sentido, é esclarecedora em torno da análise foucaultiana acerca do paradigma biopolítico atual, no qual "a Modernidade capturou a vida natural como um elemento útil e produtivo fazendo da política a arte de governo da vida humana”. A política moderna é, desse modo, uma constante biopolítica pela inscrição da vida natural, ou mesmo vida nua, nos ditames de exercício do poder.

O racismo, no âmago dessa onda biopolítica da Modernidade, é necessário, aliás, como ferramenta de seleção dos homines sacri, haja vista o interesse de preservar e cuidar da vida de algumas populações em detrimento de outras. A reflexão de Maiquel Ângelo Dezordi Wermuth e André Leonardo Copetti Santos (2016, p. 419) é importante, também, para o aprofundamento da discussão:

[...] o racismo assegura, na economia do biopoder, a função de morte, a partir do princípio de que a morte dos outros representa o fortalecimento da própria pessoa na medida em que ela é membro de uma raça ou população, ou seja, configura-se enquanto elemento de uma pluralidade unitária e viva. E é justamente aqui que reside a particularidade do racismo moderno: ele habita no fato de que ele não se encontra ligado a mentalidades, ideologias ou mentiras do poder, mas à técnica ou tecnologia do poder, atrelado ao funcionamento de um Estado que é obrigado a se utilizar da raça - da sua eliminação e da sua purificação - para que possa exercitar seu poder soberano. 
O Estado, a partir do exposto, é obrigado a fazer uso da raça com o objetivo de exercer o seu poder soberano. Isto, no âmbito da criminalidade, é perceptível frente à própria fundamentação embrionária do Estado contratual, uma vez que o pacto social surgiu para promover harmonia e paz coletivas e, consequentemente, as classes consideradas inimigas de tal intento, a exemplo de uma cultura de periculosidade dos negros, devem ser eliminadas.

O poder soberano, aliás, representa a manutenção de todos os direitos, inclusive o de matar, inerentes ao Estado de natureza, cuja sociedade, segundo Castro (2012, p. 67), era constituída integralmente por homines sacri, uma vez que todos poderiam "dispor da vida dos outros, sem cometer homicídio e sem necessidade de celebrar sacrifícios”. Hoje, porém, a definição de homines sacri depende de uma decisão soberana ou, mesmo, social.

A filosofia agambeniana (2007) traz, sob os contornos da teoria hobbesiana e da sua configuração do Leviatã, a concepção de que o Estado é formado pelo corpo de todos os indivíduos. Os corpos dos súditos, na visão de Agamben (2007), são absolutamente matáveis e consistem no novo corpo político do Ocidente, até mesmo pela defendida disseminação de um permanente estado de exceção na Contemporaneidade.

O estado de exceção refere-se à governamentalidade fundada na decisão do soberano e constituída de ações e discursos resultantes da suspensão, parcial ou total, da vigência do ordenamento jurídico. Dessa forma, a legislação prévia à instauração do regime de exceção é suspensa para a formação de um mecanismo organizado substancialmente, conforme a filosofia agambeniana (2004), por normas com força de $\mathrm{lei}^{7}$ emanadas do soberano.

O novo cenário político, originário, pois, do decisum soberano, provoca a ampliação dos poderes governamentais do executivo. O mandatário, com a outorga de plenos poderes, ao mesmo tempo em que reina um Estado com a sua legislação, parcial ou totalmente, suspensa, detém, de fato, o controle e a decisão sobre todos os fatores do Estado. Em um ambiente tal, o que ocorre é, então, um poder alicerçado no fato, na realidade, e não no direito.

A obra de Agamben (2004) abre um chamado acerca da presença constante da vontade soberana na Modernidade, inclusive nos Estados ditos de Direito, capaz de colocar todas as vidas humanas em situação potencial de ameaça a um contexto de exceção. Na acepção de Ruiz (2012, p. 5), “se por qualquer circunstância, uma pessoa ou um grupo populacional

\footnotetext{
${ }^{7}$ A grafia "lei”" é considerada, na teoria agambeniana (2004), como acertada em virtude de o estado de exceção definir uma instituição sem lei, onde a norma existe, mas não é exercida, e onde atos sem valor de lei detêm a sua força.
} 
representasse para a ordem uma ameaça real ou suposta, eles poderão sofrer a suspensão parcial ou total dos direitos para melhor controle de suas vidas".

O estado de exceção representa, assim, a governamentalidade intrínseca à sociedade regida pela biopolítica e, por conseguinte, usuária das funções inerentes ao racismo. A vida natural, ou vida nua, como elementar da biopolítica, é relevante para o poder ao cabo, aliás, de ser o objeto eliminável do corpo político-social caso o grupo populacional a que pertença seja considerado ameaçador, como pode ser vislumbrado no caso dos negros.

A tese agambeniana (2004) firma-se no transbordamento do estado de exceção nos tempos contemporâneos, o que significa a normalização do regime de exceção e, logo, a sua constatação como regra. Essa é a corroboração da análise de Walter Benjamin (1987), quando assevera que a tradição dos oprimidos demonstra que o estado de exceção a que se está submetido atualmente é a regra geral.

A partir disso, Agamben (2015) considera o campo como o local por excelência do estado de exceção, haja vista representar o lugar onde se realiza a mais absoluta condição de desumanidade. A filosofia agambeniana (2004), com alusão aos campos de concentração da Alemanha nazista, afirma que neste espaço os seres humanos são despidos do seu estatuto jurídico-político e vistos unicamente na sua vida biológica, ou seja, na sua vida nua.

Um contexto de vida nua tal resulta da situação, segundo Ruiz (2012, p. 11), que:

No campo, a vida humana é capturada pela exceção jurídica na forma de uma exclusão inclusiva. Ela é excluída dos direitos fundamentais, mas está capturada pela vontade soberana que decretou a exceção e a tornou uma vida nua, um homo sacer. O campo tem um estatuto jurídico paradoxal. Aparentemente é um território colocado fora do ordenamento jurídico normal, quando na realidade representa a exterioridade interna da ordem que o institui a partir da vontade soberana. É uma exterioridade da ordem social, porque a ela não pertence, mas sua existência revela a oculta interioridade do Estado em que continua vigente a vontade soberana como poder decisório sobre a vida humana e garantidora, em último extremo, da ordem que criou.

A par de tais considerações, o campo, na concepção de Agamben (2015), é a retratação do paradigma de governo em vigência, inclusive - insta salientar - nos chamados Estados Democráticos de Direito, devido às constantes violações de direitos humanos. Isso faz a teoria agambeniana (2007) concluir que todos os seres humanos, nos mais diversos territórios, vivem, vez ou outra, eventual ou costumeiramente, na condição de homines sacri.

A politização da vida - a biopolítica - provoca a necessária definição das vidas consideradas relevantes ou não, ou seja, das vidas dignas ou indignas de serem vividas e, em caso negativo, entra em cena a tanatopolítica, isto é, uma política sobre a morte, que, na visão 
agambeniana (2007), anda em compasso com a biopolítica. Tal decisão no contexto atual, conforme Agamben (2007, p. 146), perpassa, aliás, por todos os indivíduos, uma vez que:

Toda sociedade fixa este limite, toda sociedade - mesmo a mais moderna - decide quais sejam os seus "homens sacros". É possível, aliás, que este limite, do qual depende a politização e a exceptio da vida natural na ordem jurídica estatal não tenha feito mais do que alargar-se na história do Ocidente e passe hoje - no novo horizonte biopolítico dos estados de soberania nacional - necessariamente ao interior de toda vida humana e de todo cidadão. A vida nua não está mais confinada a um lugar particular ou em uma categoria definida, mas habita o corpo biológico de cada ser vivente.

Em um cenário como este, no qual reinam campos regidos pelo estado de exceção, alicerçados no mecanismo biopolítico e disseminados em âmbito global, a situação histórica dos negros, como integrantes de raça impura, ruim, perigosa e desnecessária, é a conformação e concretização do racismo de Estado. O resultado é a identificação da população negra, a exemplo do processo penal, da execução criminal e da violência, como detentora de vida nua.

A vida nua dos negros - ou homines sacri-vivifica-se com um nomos mantido, parcial ou totalmente, suspenso e, consequentemente, viabilizador, com supedâneo no racismo estatal, da sua morte direta ou indireta. As segregações e os homicídios corporificados com a mesma cor da pele, à luz dos informes estatísticos supramencionados, são a retratação à brasileira da raça concebida como problema biológico - e, sobremaneira, político-econômico - passível de exclusão e, pari passu, de inclusão na relação de bando.

A violência enraizada institucional e socialmente em face dos negros, nas suas mais diversas vicissitudes, pode ser desvelada, a teor de Arendt (2017b), como a própria banalidade do mal. O mal praticado corriqueiramente contra a população de cor - negra - tornou-se comum, normalizada, constante e, muitas vezes, silenciosa, não se restringindo nos confins privados, mas, também, se realizando nas áreas públicas, a exemplo da aplicação da justiça, que se vê, claramente, nos índices de encarceramento.

A diferenciação das raças, seja qual for a sua caracterização, mediante o racismo de Estado emergido nos últimos três séculos, disseminou-se nas sociedades estruturadas sob a biopolítica e se encontra impregnada no corpo político-social, de modo que o mal tenha se tornado banal. O rompimento da banalidade do mal exige, nos termos da filosofia arendtiana (2017b), que os sujeitos pensem, pois pensar é um ato perigoso, mas não pensar é ainda mais perigoso. É preciso, portanto, pensar.

\section{CONSIDERAÇÕES FINAIS}


O presente artigo propôs-se a analisar a assunção da biopolítica e a utilização do racismo como instrumento de justificação da morte em um Estado direcionado a promover a vida. A temática central envolveu a condição da população negra submetida ao encarceramento e à violência como situações de eliminação do corpo político-social através da expulsão a partir da segregação, como retrato do assassínio indireto, e da morte propriamente dita.

A filosofia de Foucault assegura que o século XVII foi marcado pela utilização dos corpos individuais em processos disciplinares com vistas à utilidade e docilidade dos seres humanos. No espaço entre os séculos XVIII e XIX, contudo, a vida biológica foi elevada a objeto do poder estatal mediante controles e regulações sobre o homem-espécie. Os referidos fenômenos de estruturação e manifestação do poder são conceituados, respectivamente, como anátomo-política e biopolítica.

Enquanto as disciplinas consistem no adestramento dos corpos a partir de atividades como separação, análise e diferenciação, os controles e as regulações atentam para elementos em escala global, como natalidade, mortalidade, produção e patologia. A biopolítica, nessa esteira, estatiza o biológico e utiliza a vida da espécie humana, ou seja, em nível populacional, como problema político.

Uma sociedade biopolítica tem o intuito de zelar pela vida, mas há situações em que a instituição estatal provoca a morte. A eliminação de certas vidas exigiu uma justificativa, a qual foi encontrada na constituição do racismo de Estado. Trata-se de um instrumento que garante e oportuniza a extinção, seja mediante o assassínio direto, seja mediante o assassínio indireto, da raça definida como perigo biológico em prol do fortalecimento da espécie humana como um todo.

A situação da população negra, especialmente no Brasil, pode ser analisada sob o prisma do racismo. A partir da obra $O$ sol é para todos, de Harper Lee, e de informes estatísticos sobre o encarceramento e a violência brasileiros, constatou-se que os negros são os "clientes" preferidos das prisões, ao mesmo tempo em que são os destinatários precípuos da violência causadora de morte, vivendo, com efeito, uma dupla exclusão, tanto do corpo político-social quanto da vida.

Os dados do Levantamento Nacional de Informações Penitenciárias - Período de Janeiro a Junho de 2020 - apontam que 66,31\% da população penitenciária é formada por pardos/pretos. Além disso, o Atlas da Violência referente a 2018 informa a taxa de homicídios 
contra pardos/pretos, a cada 100 mil habitantes, no montante de 37,8, ao passo que a de brancos, amarelos e indígenas foi de 13,9.

O sistema de justiça penal é endereçado a uma seleta camada do tecido societal, cuja razão decorre de fatores variados, sejam culturais, sejam econômicos, sejam políticos. $\mathrm{O}$ viés racial, porém, é elementar nesta conformação do poder, notadamente repressivo-punitivo, o qual institucionaliza o discurso social de recrudescimento da ação estatal frente à criminalidade. O resultado, todavia, é a seleção de um público-alvo como razão de ser da violência.

Os diplomas legais decorrem, em tese, da soberania popular. Esta soberania popular, contudo, é seletiva. Esta seletividade, com efeito, afeta uns em detrimento de outros. Estes uns e outros, às vezes, comandam e, às vezes, são comandados. O biopoder tem como intuito, especialmente no seio da governamentalidade, o bem da coletividade, embora não conduza, necessariamente, ao bem de todos. Esta é, aliás, a chave de compreensão do dilema em voga.

Nessa senda, o Ancien Régime volta à cena com o racismo de Estado: o direito de matar se relaciona com o direito de viver. Não se estabelece, assim, uma contradição com a biopolítica, mas uma seleção entre as vidas abrangidas e desabrigadas, entre as vidas dignas e indignas, entre bíos e zoé. Esses caracteres estão nas esferas tanto institucional como social, seja na persecução penal, seja na violência, enclausurando e matando a população negra.

A escravidão brasileira direcionou os seus esforços em face dos negros. O ingresso de africanos no País foi substancial no transcurso de três séculos até a abolição ocorrida no dia 13 de maio de 1888. Com o fim deste modelo, porém, tornou-se necessário estabelecer uma nova ferramenta de estratificação do tecido societal. Para isso, a adoção das raças foi válida à nivelação dos corpos e das vidas que importam. Assim, modificam-se as estruturas e suas dinâmicas, mas o racismo continua o mesmo.

A população negra, com base nessas reflexões, vive na Contemporaneidade, à luz da filosofia de Agamben, na condição de homo sacer, cuja vida é eliminável do tecido societal e despida de direitos humanos. Tais seres humanos, vistos em sua cor da pele, são banidos excluídos - do corpo político-social e transformados - incluídos - em vida nua, isto é, em vida meramente existencial e sem relevância ao poder constituído e à sociedade.

Tal situação, na esteira do cenário atinente aos negros, com escopo no racismo no âmbito da persecução penal e da violência, é a configuração, por conseguinte, do estado de exceção difundido em múltiplos campos do território. Estes consubstanciam-se em razão da eliminação da raça impura, ruim, perigosa e desnecessária com o desígnio de privilegiar e atender aos interesses da dita raça superior. 
A par disso, alusivamente ao título da obra literária de Harper Lee, constata-se que o racismo, como instrumento biopolítico, faz com que muitos seres humanos, analisados, talvez, unicamente sob o caráter da cor da pele, possam não ver mais o sol nascer - pois, mortos, estarão embaixo da terra - ou vê-lo apenas atrás das grades. O destino dos negros é, neste sentido, a expulsão da vida social pelo encarceramento ou a morte propriamente dita.

A seletividade biopolítica atual, especialmente a partir dos índices de encarceramento e de violência no tocante aos negros, no Brasil, demonstra, portanto, corroborando a hipótese embrionária e atendendo aos objetivos desta pesquisa, a utilização do racismo de Estado como ferramenta de assassínio direto e indireto de raça com fundamento na cor da pele. Trata-se da retratação brasileira da banalidade do mal.

O regime de biopoder não impede a resistência aos seus meandros negativos. Há, aliás, um cariz positivo na sua configuração, o que exige, no entanto, que seja desabrochado. Os indivíduos devem assumir a condição de sujeitos - e não somente de objetos - das tessituras político-social e angariar a atuação do Estado com atenção ao bem comum. Há, todavia, um obstáculo crucial: o discurso social (e institucionalizado) de ratificação da hierarquia racial. O sublime desafio - que, a bem da verdade, necessita de aprofundamento descritivo e analítico é arrostá-lo.

Impera-se a tarefa, à luz do diagnóstico acima traçado, de reforçar a defesa dos direitos humanos como valores de titularidade de todos os seres humanos e não direcionados somente a selecionadas raças como evidenciado na história e na atualidade do Brasil. Esta é, por fim, a missão cívico-democrática de reconhecimento da humanidade constitutiva de todas as cores formativas do Estado Democrático de Direito, nos termos da Constituição Federal de 1988.

\section{REFERÊNCIAS}

AGAMBEN, Giorgio. Estado de exceção. Tradução de Iraci D. Poleti. São Paulo: Boitempo Editorial, 2004.

AGAMBEN, Giorgio. Homo sacer: o poder soberano e a vida nua I. Tradução de Henrique Burigo. Belo Horizonte: Editora UFMG, 2007.

AGAMBEN, Giorgio. Meios sem fim: notas sobre a política. Tradução de Davi Pessoa Carneiro. Belo Horizonte: Autêntica, 2015.

ALEXANDER, Michelle. A nova segregação: racismo e encarceramento em massa. Tradução de Pedro Davoglio. São Paulo: Boitempo, 2018. 
ALMEIDA, Silvio. Racismo estrutural. São Paulo: Sueli Carneiro; Polén, 2019.

ARENDT, Hannah. A condição humana. Tradução de Roberto Raposo. 10. ed. Rio de Janeiro: Forense Universitária, 2007.

ARENDT, Hannah. Eichmann em Jerusalém: um relato sobre a banalidade do mal. Tradução de José Rubens Siqueira. 21. reimp. São Paulo: Companhia das Letras, 2017b.

ARENDT, Hannah. Origens do totalitarismo. Tradução de Roberto Raposo. 7. reimp. São Paulo: Companhia das Letras, 2017a.

AYUB, João Paulo. Introdução à analítica do poder de Michel Foucault. São Paulo: Intermeios, 2015.

BARATTA, Alessandro. Criminologia crítica e crítica do direito penal: introdução à sociologia do direito penal. Tradução de Juarez Cirino dos Santos. 6. ed. 5. reimp. Rio de Janeiro: Revan, 2018.

BENJAMIN, Walter. Obras escolhidas: magia e técnica, arte e política. Tradução de Sergio Paulo Rouanet. 3. ed. São Paulo: Brasiliense, 1987.

BORGES, Juliana. Encarceramento em massa. São Paulo: Sueli Carneiro; Polén, 2019.

BRASIL. Levantamento Nacional de Informações Penitenciárias - Período de Janeiro a Junho de 2020. Brasília: Departamento Penitenciário Nacional, 2021. Disponível em: https://www.gov.br/depen/pt-br/sisdepen. Acesso em: 23 mar. 2021.

CASTRO, Edgardo. Introdução a Giorgio Agamben: uma arqueologia da potência. Tradução de Beatriz de Almeida Magalhães. Belo Horizonte: Autêntica, 2012.

CASTRO, Edgardo. Lecturas foucaulteanas: una historia conceptual de la biopolítica. La Plata: Unipe Editorial Universitária, 2011.

DIAS, Camila Caldeira Nunes. Encarceramento, seletividade e opressão: a "crise carcerária" como projeto político. São Paulo: Friedrich Ebert Stiftung. Análise no 28/2017. Disponível em: http://library.fes.de/pdf-files/bueros/brasilien/13444.pdf. Acesso em: 29 jul. 2019.

DUARTE, André de Macedo. De Michel Foucault a Giorgio Agamben: a trajetória do conceito de biopolítica. In: SOUZA, Ricardo Timm de; OLIVEIRA, Nythamar Fernandes de. (Orgs.). Fenomenologia Hoje III - Bioética, biotecnologia, biopolítica: v. 3. Porto Alegre: Editora da PUCRS, 2008. p. 63-87.

ESPOSITO, Roberto. Bios: biopolítica e filosofia. Lisboa: Edições 10, 2010.

FLAUZINA, Ana Luiza Pinheiro. Corpo negro caído no chão: o sistema penal e o projeto genocida do Estado brasileiro. Rio de Janeiro: Contraponto, 2008.

FOUCAULT, Michel. Em defesa da sociedade: curso no Collège de France (1975-1976). Tradução de Maria Ermantina Galvão. São Paulo: Martins Fontes, 2005. 
FOUCAULT, Michel. História da sexualidade I: a vontade de saber. Tradução de Maria Thereza da Costa Albuquerque e J. A. Guilhon Albuquerque. 13. ed. Rio de Janeiro: Edições Graal, 1999.

FOUCAULT, Michel. História da sexualidade I: a vontade de saber. Tradução de Maria Thereza da Costa Albuquerque e J. A. Guilhon Albuquerque. 22. reimpr. Rio de Janeiro: Edições Graal, 2012.

FOUCAULT, Michel. Vigiar e punir. Tradução de Raquel Ramalhete. 41. ed. Petrópolis: Vozes, 2013.

GADAMER, Hans-Georg. Verdade e método: traços fundamentais de uma hermenêutica filosófica. Tradução de Flávio Paulo Meurer. 3. ed. Petrópolis: Vozes, 1999.

HEIDEGGER, Martin. Ser e tempo: parte 1. Tradução de Márcia de Sá Cavalcante. 7. ed. Petrópolis: Vozes, 1998.

HOBBES, Thomas. Leviatã: ou matéria, forma e poder de um Estado eclesiástico e civil. Tradução de Rosina D’Angina. São Paulo: Martin Claret, 2017.

INSTITUTO DE PESQUISA ECONÔMICA APLICADA (IPEA). Atlas da Violência 2020. Brasília: Instituto de Pesquisa Econômica Aplicada, 2020. Disponível em: https://www.ipea.gov.br/atlasviolencia/download/24/atlas-da-violencia-2020. Acesso em: 23 mar. 2021.

LEE, Harper. O sol é para todos. Disponível em: http://lelivros.love/book/download-o-sol-epara-todos-harper-lee-em-epub-mobi-e-pdf/. Acesso em: 31 jul. 2018.

LÉVI-STRAUSS, Claude. De perto e de longe. Tradução de Léa Mello e Julieta Leite. São Paulo: Cosac \& Naify, 2005.

LOCKE, John. Segundo tratado sobre o governo. Tradução de Alex Marins. São Paulo: Martin Claret, 2002.

MBEMBE, Achille. Necropolítica. Arte \& Ensaios, Rio de Janeiro, n. 32, p. 122-151, 2016. Disponível em: https://revistas.ufrj.br/index.php/ae/article/view/8993/7169. Acesso em: 17 out. 2019.

MORAIS, Danilo de Souza; SINHORETTO, Jacqueline. Violência e racismo: novas faces de uma afinidade reiterada. Revista de Estudios Sociales, Bogotá, n. 64, p. 15-26, abr./jun. 2018. Disponível em: https://revistas.uniandes.edu.co/doi/pdf/10.7440/res64.2018.02. Acesso em: 07 maio 2020.

PELBART, Peter Pál. Vida capital: ensaios de biopolítica. São Paulo: Iluminuras, 2011.

ROUSSEAU, Jean-Jacques. O contrato social. Tradução de Edson Bini. 2. ed. São Paulo: Edipro, 2015. 
RUIZ, Castor Mari Martín Bartolomé. A sacralidade da vida na exceção soberana, a testemunha e sua linguagem: (re) leituras biopolíticas da obra de Giorgio Agamben. Cadernos IHU, ano 10, n. 39. São Leopoldo: Instituto Humanitas Unisinos, 2012.

SCHWARCZ, Lilia Moritz. Nem preto nem branco, muito pelo contrário: cor e raça na sociabilidade brasileira. 4. reimp. São Paulo: Claro Enigma, 2018.

SCHWARCZ, Lilia Moritz. O espetáculo das raças: cientistas, instituições e questão racial no Brasil (1870-1930). 6. reimp. São Paulo: Companhia das Letras, 2005.

SINHORETTO, Jacqueline; SILVESTRE, Giane; SCHLITTLER, Maria Carolina. Desigualdade racial e segurança pública em São Paulo: letalidade policial e prisões em flagrante. São Carlos: Universidade Federal de São Carlos, 2014. Disponível em: http://www.ufscar.br/gevac/wp-content/uploads/Sum\%C3\%A1rioExecutivo_FINAL_01.04.2014.pdf. Acesso em: 07 maio 2020.

STEIN, Ernildo. Compreensão e finitude: estrutura e movimento da interrogação heideggeriana. Ijuí: Unijuí, 2001.

WERMUTH, Maiquel Ângelo Dezordi. Biopolítica e polícia soberana: a sociedade escravocrata como chave de compreensão da violência e da seletividade punitiva no Brasil. Revista Direitos Fundamentais e Democracia, Curitiba, v. 23, n. 3, p. 284-309, set./dez. 2018. Disponível em: http://revistaeletronicardfd.unibrasil.com.br/index.php/rdfd/article/view/1262/564. Acesso em: 24 jul. 2019.

WERMUTH, Maiquel Ângelo Dezordi. O Brasil e a criminalização da pobreza: a imposição do medo do direito penal como instrumento de controle social e de desrespeito à dignidade humana. In: BEDIN, Gilmar Antonio (Org.). Cidadania, direitos humanos e equidade. Ijuí: Unijuí, 2012.

WERMUTH, Maiquel Ângelo Dezordi; SANTOS, André Leonardo Copetti. Michel Foucault e a arqueologia/genealogia do poder: da sociedade disciplinar à biopolítica. Quaestio Iuris, Rio de Janeiro, v. 9, n. 1, p. 376-404, 2016. Disponível em: https://www.epublicacoes.uerj.br/index.php/quaestioiuris/article/view/17727. Acesso em: 07 maio 2020.

WILLIAMS, Davi; PRIEST, Naomi. Racismo e saúde: um corpus crescente de evidência internacional. Sociologias, Porto Alegre, v. 17, n. 40, p. 124-174, set./dez. 2015. Disponível em: http://www.seer.ufrgs.br/index.php/sociologias/article/view/61049/35912. Acesso em: 07 maio 2020.

YOUNG, Jock. A sociedade excludente: exclusão social, criminalidade e diferença na modernidade recente. Tradução de Renato Aguiar. Rio de Janeiro: Revan, 2002.

ZAFFARONI, Eugenio Raúl; PIERANGELI, José Henrique. Manual de direito penal brasileiro: parte geral. 4. ed. rev. São Paulo: Revista dos Tribunais, 2002. 
ZAMORA, Maria Helena Rodrigues Navas. Desigualdade racial, racismo e seus efeitos.

Fractal: Revista de Psicologia, Rio de Janeiro, v. 24, n. 3, p. 563-578, set./dez. 2012.

Disponível em: http://periodicos.uff.br/fractal/article/view/4915/4757. Acesso em: 07 maio 2020.

Trabalho recebido em 08 de maio de 2020

Aceito em 24 de março de 2021 